\title{
KEMISKINAN, KORUPSI DAN TERORISME DALAM PENDEKATAN KAUSALITAS
}

\author{
Jonson Rajagukguk ${ }^{1}$ Maringan Panjaitan ${ }^{2}$ \\ Fakultas Ilmu Sosial dan Ilmu Politik, Universitas HKBP Nommensen \\ jonson.rajagukguk@uhn.ac.id ${ }^{1}$, maringanpanjaitan@uhn.ac.id ${ }^{2}$
}

\begin{abstract}
ABSTRAK : Munculnya gerakan teroris di berbagai belahan dunia, termasuk negara Indonesia tentu punya faktor pemicu dan faktor pendorong. Terorisme tidaklah berdiri sendiri sebagai sebuah gerakan yang dianggap sudah menjadi Ideologi. Para teroris tidak takut mati dan terus melakukan aksinya dengan berbagai iming iming yang bersumber dari radikalisme agama, dimana ada pemahaman agama yang salah kaprah. Apa yang membuat gerakan terorisme ini terus tumbuh dan sangat sulit untuk dihenatikan. Banyak kajian yang menyebut gerakan ini ada yang melatarbelakangi dengan berbagai faktor yang bisa memperkuat basis dukungan kepada mereka. Artinya, gerakan teroris ini adalah sebab akibat yang bisa kita kaji dengan pendekatan akademis, dan murni tidak melulu pemahaman agama yang salah. Salah satu faktor pemicu gerakan teroris ini adalah lingkaran kemiskinan yang membuat masyarakat tidak percaya pada hukum dan pemerintah. Belum lagi korupsi yang sangat masif bisa saja membuat masyarakat kehilangan kepercayaan pada institusi negara dan institusi hukum. Artinya, kalau mau meminimalisir gerakan teroris ini maka saatnya diperkuat penegakan hukum, pengentasan kemiskinan dan pemberantasan korupsi yang bisa membuat tata kelola negara makin bagus sehingga kepercayaan masyarakat bisa tumbuh pada institusi negara.
\end{abstract}

\section{Kata Kunci: Kemiskinan, Korupsi Dan Terorisme}

\begin{abstract}
As a nation that is scientifically and technologically strong, the United States, which is called the world police, is certainly not an exaggeration. Public policies made by the United States are always loaded with economic interests. Regional domination framed by equal state relations on the basis of human rights has always been the entry point for the American nation in carrying out domination politics. Public policy made by the United States is certainly oriented to its interests. Naturally, the concept of the American nation Number one by its leaders has certainly made its global policy always oriented to its interests. In the current global arena, the United States of America always makes policies that benefit itself in this case its economic interests.
\end{abstract}

Keywords: Future, Global Public Policy, Economic Interest

\section{PENDAHULUAN}

Gejala radikalisme berbalut agama kembali menjadi ancaman bagi negara kita. Berbagai aktivitas teroris dan berbagai aktivitas terorisme lainnya membuat pemerintah pusing dan mengeluarkan tenaga ekstra ketat dalam mengantisipasinya. Nampaknya pendekatan keamanan masih didahulukan untuk mencegah berbagai tindakan dan perilaku radikal. Kalau kita berhitung dengan teori efektivitas, apakah pendekatan keamanan relevan dalam mencegah munculnya gerakan radikalisme atau terorisme? Negara kita tidak pernah melihat sebuah permasalahan dengan utuh dan menyeluruh. Kita adalah bangsa yang reaktif jika berhadapan dengan sebuah masalah. Sebagai contoh, ketika muncul penyakit muntaber di komunitas sebuah masyarakat, pemerintah asyk mengimbau untuk hidup sehat dan menjaga kebersihan lingkungan. Kita tidak pernah berpikir dengan lingkungan yang bersih sudah pasti penyakit muntaber tidak akan muncul. 
Padahal jika pola hidup sehat dan bersih lingkungan penyakit kecil kemungkinan muncul.

Banyak lagi berbagai persoalan kebangsaan dan kemasyarakat yang selalu kita lihat dengan sepotong-sepotong. Melihat gejala radikalisme dan terorisme serta bentuk kekerasan berbalut agama, atau kriminal umum selalu kita dahulukan masalah perilaku personalnya yang mau berbuat demikian. Kita melihat perilaku kekerasan dan pelaku teror adalah oknum yang tidak bertanggung jawab, tidak punya spirit kebangsaan yang tinggi, manusia yang tidak bermoral, lantas sesederhana itukah masalahnya? Tentu tidak, kekerasan berbalut agama, radikalisme, dan kriminal umum bukan persoalan patuh dan tidak patuh kepada hukum. Banyak variabel untuk menjawabnya mengapa sampai muncul. Persoalannya, pernahkah pemerintah melihat secara utuh dan mencari solusi yang menyeluruh mengapa sampai muncul gejala radikalisme seperti yang terjadi sekarang ini? Sekali lagi, radikalisme adalah sesuatu yang tidak kita inginkan. Menyelesaikan masalah ini perlu melihat dengan utuh apa akar persoalannya mengapa sampai muncul. Pendekatan keamanan tidak akan bisa efektif mengantisipasi ini. Itu hanya tindakan reaksioner karena ada reaksi.

Salah satu yang menyebabkan munculnya gerakan-gerakan ekstrim kiri adalah karena persoalan kemiskinan dan ketidakadilan dalam berbagai hal. Ketidakadilan dalam bidang ekonomi, hukum, politik, sosial budaya, dan pendidikan. Kemiskinan di satu sisi adalah ketidakberdayaan negara dalam mencapai tujuannya sebagaimana yang diamanatkan oleh konstitusi. Sementara pada sisi lain mengapa masyarakat miskin bisa saja memang karena faktor SDM, kemalasan dalam bekerja. Tetapi yang pasti, kemiskinan bukanlah pilihan bagi masyarakat. Siapapun pasti punya keinginan untuk lepas dari perangkap kemiskinan. Seorang kawan pernah berlelucon pada saat makan siang. "Kriminal dan tindakan teroris muncul karena kemiskinan. Logikanya sangat sederhana. Masyarakat miskin gampang frustrasi dan tidak takut mati. Jadi ketika di didoktrin untuk mati dengan mengatakan kepada dia, "kalau kau mati, kau akan masuk surga dan semua utangmu akan lunas. Sementara kalau kau hidup, maka hidupmu akan seperti-seperti ini dan bahkan kau akan menderita seumur hidup. Jadi", lebih baik kau bunuh diri saja dan membunuh orang kaya sana sebagai dalang atau penyebab kau miskin maka kau akan masuk surga. Si kawan yang frustrasi gampang menerima dan melakukan apa yang diinginkan oleh gembong terorisme. Sementara katanya lagi sambil bergurau, :kenapa orang kaya takut mati? Jawabnya sangat sederhana, dia takut mati karena masih bisa menikmati hidup ini dengan tenang.

Kembali kepada konteks persoalan, benarkah kemiskinan dan ketidakadilan dalam berbagai hal memicu munculnya gerakan radikalisme? Memang sangat sulit menjawab persoalan ini. Tetapi sedikit banyaknya masalah kemiskinan dan ketidakadilan dalam berbagai hal akan memacu gerakan-gerakan radikalisme.

Masalah ketimpangan ekonomi membuat kemiskinan terus menguat. Akses masyarakat miskin kepada pelayanan publik seperti kesehatan dan lainnya membuat masyarakat makin terpinggirkan. Sementara angka korupsi semakin marak sebagai sebuah kebiasaan bagi pejabat. Pemberantasan korupsi yang sangat lemah, penegakan hukum yang kurang maksimal tentu membuat korupsi sulit untuk diberantas. Artinya, kemiskinan dan korupsi adalah dua hal yang tidak bisa dipisahkan. Untuk itu, perlu upaya atau gerakan untuk mencegah korupsi yang pada akhirnya berdampak pada kemakmuran. Korupsi dan kemiskinan adalah dua 
hal yang saling berkaitan. Jika korupsi dan kemiskinan tetap tinggi maka gerakan terorisme dengan segala bentuknya pasti akan muncul sebagai sebuah bahaya laten. Tulisan ini mengulas hubungan korupsi, kemiskinan dan terorisme.

Dengan melihat latar belakang di atas maka tujuan dari penulisan makalah deskriptif ini adalah:

1. Melihat sejauh mana hubungan angka kemiskinan dan korupsi bisa memicu gerakan radikalisme

2. Melihat hubungan antara korupsi sebagai kejahatan kemanusiaan dengan ketimpangan ekonomi

3. Memberikan masukan pencegahan korupsi sehingga bisa meminimalisir gerakan teroris yang sedang dihadapi oleh negara saat ini.

\section{METODE PENELITIAN}

Metode penelitian makalah ini adalah metode kualitatif dimana penulis menggunakan pedekatan kualitatif deskriptif. Sugiyono (2015) mengatakan metode penelitian kualittaif adalah metode penelitian yang berlandaskan pada filsafat pospositivisme, digunakan untuk meneliti pada kondisi obyek yang alamiah yang hasilnya lebih menekankan makna daripada generalisasi. Dalam tulisan ini penulis memberikan paparan mengenai hubungan korupsi, kemiskinan sebagai faktor yang memicu gerakan terorisme sehingga permasalahan bisa terurai dengan baik dan bisa memberikan gambaran mengenai faktor yang memicu gerakan teroris.

\section{PEMBAHASAN}

Korupsi dan koruptor sesuai dengan bahasa aslinya bersumber dari bahasa latin corruptus, yakni berubah dari kondisi yang adil, benar dan jujur menjadi kondisi yang sebaliknya Corruptio dari kata kerja corrumpere, yang berarti busuk, rusak, menggoyahkan, memutar balik, menyogok, orang yang dirusak, dipikat, atau disuap (Muhammad Azhar: 2003). Dalam hukum pidana definisi ialah: Perbuatan yang buruk seperti penggelapan uang, penerimaan uang sogok dan sebagainya. Dalam Kamus Umum Bahas Indonesia, .Korupsi diartikan Suatu hal yang buruk dengan bermacam ragam artinya bervariasi menurut waktu tempat dan bangsa.

Samuel Huntington dalam buku Political Order in Changing Societies, mendefinisikan korupsi sebagai behavior of public officials with deviates from accepted norms in order to serve private ends (1968: 59). Melihat dari definisi tersebut jelas bahwa korupsi tidak hanya menyangkut aspek hukum, ekonomi dan politik tetapi juga menyangkut perilaku manusia (behavior) yang menjadi bahasan utama serta norma (norms) yang diterima dan dianut masyarakat.

Dari pengertian di atas dapat kita lihat betapa korupsi itu sangat merugikan dan memang sesuatu yang harus dicegah. Korupsi bisa berdampak besar bagi tata kelola negara. Untuk itu, upaya pencegahan bisa dilakukan dengan optimal agar pembangunan bisa jalan dan kemiskinan juga bisa teratasi dengan baik. Kemiskinan adalah sesuatu yang bisa memicu banyak hal, termasuk kriminal dan juga terorisme. 
Dalam banyak literatur dan juga studi kepustakaan banyak mendefenisikan kemiskinan dalam berbagai aspek. Kemiskinan diartikan sebagai suatu keadaan dimana seseorang tidak sanggup memelihara dirinya sendiri sesuai dengan taraf kehidupan kelompok dan juga tidak mampu memanfaatkan tenaga mental maupun fisiknya dalam kelompok tersebut (Soekamto 2005). Kemiskinan menjadi lain bagi mereka yang turut dalam urbanisasi tetapi gagal mencari pekerjaan. Bagi mereka pokok persoalan kemiskinan disebabkan tidak mampu memenuhi kebutuhan-kebutuhan primer sehingga timbul tuna karya, tuna wisma dan lain sebagainya.Secara sosiologis, sebab-sebab timbulnya problema adalah karena salah satu lembaga kemasyarakatan tidak berfungsi dengan baik yaitu lembaga kemasyarakatan dibidang ekonomi.

Keluarga miskin (prasejahtera) adalah keluarga yang belum memenuhi salah satu atau lebih syarat berikut :

1. Bisa makan dua kali sehari atau lebih

2. Mempunyai pakaian yang berbeda untuk berbagai keperluan

3. Lantai rumah bukan tanah

4. Bila anaknya sakit dibawa berobat ke sarana/ke puskesmas

Menurut Parsudi Suparlan (dalam Malo, 2006:17) mengatakankemiskinan sebagai suatu standar tingkat hidup yang rendah, yaitu adanya suatu tingkat kekurangan materi pada sejumlah ataui segolongan orang dibandingkan dengan standar kehidupan yang umum berlaku dalam masyarakat yang bersangkutan. Dengan demikian pada dasarnya kemiskinan mengacu pada keadaan serba kekurangandalam pemenuhan sejumlah kebutuhan, seperti sandang, pangan, papan, pekerjaan, pendidikan, dan pengetahuan.

Kembali kepada masalah kemiskinan dan korupsi tadi yang bisa memicu gerakan teroris tentu butuh perhatian dari pemerintah untuk mengambil kebijakan supaya ini jangan terjadi dan bisa dicegah. Terorisme sebagai sebuah ancaman yang sangat membahayakan saatnya dicarikan solusi bagaimana mengatasinya. Gerakan teroris ini sangatlah membahayakan. Apa yang terjadi di Kota Makassar merupakan perbuatan yang sangat merugikan dan merusak. Padahal agama tidak pernah mengajarkan terorisme dan radikalisme. Apa yang dilakukan oleh sang teroris Makassar dan mabes Polri adalah ulah oknum yang salah dalam memahami agamanya. Tindakan ini tentu sangat kita sayangkan. Dalam hal ini kesamaan visi dan misi perlu kita bangun agar tidak terjadi pengalamatan teroris pada agama tertentu karena aksi teror sangat bertentangan dengan agama.

Mengingat aksi teror ini merupakan sebuah siklus yang sangat menakutkan dan kita tidak tahu kapan terjadi lagi, antisipasi dan menganalisis akar penyebabnya hanya merupakan tindakan yang bisa kita lakukan. Ketika teror seperti ini muncul tentu pertanyaan yang sangat sederhana kita kemukakan ke publik, apa latar belakang sehingga gerakan teror yang sangat menakutkan ini bisa terjadi? Ketika akar penyababnya (the root cause) sudah dapat, sudah maksimalkah pemerintah mengupayakan solusinya sehingga antisipipasi meminimalisasi aksi lanjutan bisa diupayakan?

Apa yang terjadi di Makassar dan juga Bom Mabes Polri sangat kita sayangkan karena di tengah kelesuan ekonomi negara kita karena pandemi Covid19 ini justru ancaman baru terus datang dan juga sangat menakutkan kita bersama. Artinya, belum masalah seelsai muncullah lagi masalah baru yang menguras energi bangsa kita. Aksi teror ini membuat trauma kolektif terjadi karena bisa saja terjadi tanpa diduga. Antisipasi yang kita lakukan bisa juga lengah karena 
keterbatasan sumber daya (limited resources) dan juga keterbatasan kita dalam banyak hal. Ruang negara yang sangat besar mulai jumlah penduduk yang sangat besar dan wilayah yang sangat besar tentu memberi ruang (make room) pada gerakan terois ini.

Kembali kepada antisipasi tadi. Antisipasi tentu harus diperkuat kajian, apa yang menjadi pemicu muncullanya gerakan ini? Apakah karena faktor kemiskinan dan ketimpangan ekonomi, apakah karena penegakan hukum yang lemah, apakah karena keberagamaan kita yang salah? Atau karena pendidikan masyarakat yang sangat rendah? Kajian akademis sah-sah saja dan itu musti harus dilakukan karena kajian akademis banyak digunakan referensi negara dalam mengantisipasi gerakan teroris ini. Sebelum memulai membahasnya lagi, tentu harus kita ingatkan teror koruptor juga sangat berbahaya bagi negara (the terror of the corruptor is very dangerous ). Bagi sebagian orang melihat aksi sadis terorisme bom bunuh diri secara nyata memakan korban dianggap sangat sadis karena nyawa langsung melayang. Tetapi korupsi juga merupakan aksi yang sangat sadis juga dan membunuh warga miskin. Korupsi juga merupakan wujud pembunuhan kepada rakyat secara pelan -pelan karena dampak korupsi masyarakat menjadi miskin. Bayangkan, yang korupsi itu adalah pejabat negara dan pengusaha yang sudah mapan secara ekonomi. Konon lagi menambah pundi -pundinya dengan cara biadab, 'menggarong' uang negara. Bukankah ini tidak merupakan aksi teror juga kepada masyarakat yang tidak tahu apa-apa?

Dalam perjalanan penegakan hukum kepada koruptor bisa dibilang sangat lemah. Kalau kita komparasi dengan cara atau metode Tiongkok (China) dalam memerangi korupsi sangat kontras dengan negara kita. Pemberlakukan hukuman mati bagi koruptor di Hongkon dan Tiongkok membuat negara tersebut bisa meminimalisasi korupsi. Pemberantasan korupsi yang berhasil di China membuat negara tersebut menjadi raksasa ekonomi dunia yang sangat ditakuti. Level bangsa Asia karena peran China dalam perekonomian global mulai mensejajarkan diri dengan bangsa Eropa (USA). Tentu ini adalah sebuah pesan psikologis bahwa bangsa Asia bisa sejajar dengan Eropa. China adalah sebuah negara yang berhasil dalam misi suci pemberantasan korupsi dan berhasil menjadi salah satu kekuatan ekonomi dunia (world economic power).

Di negara kita sangat kontras, korupsi sangat masif dan hukuman bagi koruptor kayaknya tidak setimpal. Ketika UU sudah mengatakan korupsi adalah kejahatan kemanusiaan (extra ordinary crime) ternyata pelakunya masih ada, bahkan sekelas menteri tertangkap tangan oleh KPK. Ini tentu sangat memalukan. Korupsi juga merupakan bentuk teror kepada negara. Kembali kepada akar masalah dan latar belakang aksi terorisme tadi, apa yang dilakukan oleh ekstrimisme dan terorisme atas nama apapun sungguh merupakan wujud manusia barbar, brutal, dan juga sangat biadab. Manusia yang tidak tahu apa-apa harus jadi korban (meninggal) demi terwujudnya ambisi para teroris yang latar belakang munculnya gerakan terorisme mereka masih sulit kita pahami.

Apa sebenarnya yang dicari para teroris ini sehingga sampai hati, tega, bahkan merasa tidak bersalah dalam membunuh manusia yang tidak berdosa? Banyak studi mengemukakan mengenai terorisme ini, tetapi itu jangan jadi justifikasi untuk mendukung tindakan mereka. Terlepas dari ketidakadilan ekonomi (economic injustice) dan ketidakadilan politik lainnya yang sering mereka paksakan sebagai pembenaran, sungguh tidak masuk akal membunuh 
manusia yang tidak mengetahui apa-apa hanya karena ketimpangan ekonomi (economi inequality) semata.

Di negara kita sampai sekarang masalah teroris belum tuntas dan masih banyak potensi yang bakal muncul. Ini harus kita waspada. Sebagai contoh, tragedi di Poldasu yaang memakan korban adalah wujud nyata betapa aksi teroris sungguh harus diantisipasi dengan segala cara. Pembunuhan yang tidak mengenal kemanusiaan itu patut kita jadikan sebagai renungan khusus bahwa teroris sudah kehilangan nilai moral yang sangat tinggi. Kalau sudah ada niat untuk membunuh manusia yang tidak berdosa apa lagi yang mau dikata. Inilah puncak dari krisis moral yang membuat manusia hidup pada sebuah era barbarisme atau kanibalisme kemanusiaan (humanitarian cannibalism) secara sadis. Tetapi saya masih meyakini semua agama tidak akan pernah mengajari tindakan teroris kepada jemaat atau umatnya. Dalam konsep semua agama, baik Islam, Kristen, Budha, Hindu, Konghucu, mengajarkan nilai-nilai kasih (teach the values of love) dan persaudaraan yang tinggi. Sekalipun kita punya metode tersendiri dalam memuja Tuhan, tetapi pada prinsipnya ajaran untuk berbuat baik, menghormati sesama, saling mengasihi selalu diajarkan oleh para tokoh agama yang berdasar atas kita suci masing-masing. Tidak ada agama yang mengajarkan kekerasan. Kalaupun kekerasan berlabelkan agama ada, tetapi itu adalah tindakan pribadi yang tidak bisa dibenarkan.

Pendapat umum tentang terorisme di dunia saat ini, lebih kurang terfokus di sekitar fundamentalisme agama. Beberapa tahun terakhir di luar negeri terbit sejumlah buku tentang kekerasan berbendera agama di Indonesia, yang mengaitkannya dengan fundamentalisme agama. Zachary Abuza dalam buku "Political Islam and Violence in Indonesia" (2007), termasuk yang mencoba melihat hubungan-hubungan itu. Terkait aksi-aksi kekerasan bermotif agama yang dilakukan oleh para pelaku teror, ada hal-hal yang menjadi perhatian pengamat, di antaranya, kemunculan politik sektarian (identitas) setelah kejatuhan Orde Baru, berkembangnya faham yang memilih cara-cara kekerasan, terjadinya kekerasan komunal seperti di Ambon dan Poso, serta munculnya beberapa kelompok radikal yang memilih cara kekerasan yang memiliki jaringan nasional, regional, dan global. Selain itu, studi-studi tentang terrorism financing juga memperkuat cara pandang itu, dengan berusaha mengerti bagaimana jaringan global terorisme saling mendukung dari sisi pembiayaan, termasuk dalam kasus Indonesia (Giraldo \& Trinkunas, eds, 2007; Bersteker \& Eckert, eds, 2008).

Kedepan, apa yang harus dilakukan oleh pemerintah agar bibit terorisme itu tidak berkembang lagi dan terorisme itu tidak mendapat ruang di negara kita ini? Mungkin usulan yang bisa dilakukan adalah:

Pertama, proyek pengembangan hidup toleran dan hidup harmoni secara sosial saatnya digalakkan. Dalam hal ini pemerintah harus fokus upaya apa yang bisa dilakukan agar toleransi antar umat agama dan antar suku bisa membangun komunitas yang slaing menghargai. Untuk itu, saatnya pemerintah aktif dalam membangun dialog antar umat beragama yang berbeda agar terjadlin kohesi sosial yang saling mengkonstruksi. Saat ini sudah ada program moderasi beragama oleh Kemenag dan itu harus terus didorong dan diimbangi dengan peningkatan mutu kualitas hidup masyarakat. Tanpa diimbangi oleh kualitas pembangunan yang mumpuni, dan program pendidikan yang terakses kepada semua warga, mustahil program moderasi beragama berjalan dengan baik. 
Kedua, Saatnya lembaga pendidikan dari strata paling bawah sampai pendidikan tinggi fokus mengembangkan kurikulum multikultural dengan penekanan implementasi Ideologi Pancasila dan kebhinnekaa bangsa sebagai anugerah dari Tuhan. Dengan demikian generasi yang lahir dari lembaga pendidikan adalah generasi yang mampu merawat keberagaman bangsa. Jelasnya lagi, lembaga pendidikan adalah "role model" proyek pengembangan multikultural.

Ketiga, penegakan hukum yang berkadilan harus dilakukan (equality before the law). Dengan adanya penegakan hukum yang berkeadilan dengan prinsip kesetaraan bahwa semua warga negara sama di depan hukum justru membangun "modal sosial" (social capital) dalam bentuk "trust" dari masyarakat. Masyarakat yang percaya pada hukum adalah jaminan (guarantee) dalam negara demokrasi. Dengan terbangunnya kepercayaan masyarakat pada institusi hukum maka program pembangunan bisa berjalan dengan baik dan bisa mencegah gerakan radikalisme, dan gerakan intoleran.

Keempat, mencegah ketimpangan ekonomi yang terlalu besar. Ketimpangan ekonomi yang terjadi saat ini bisa memicu gerakan -gerakan radikal. Sebagai contoh $1 \%$ orang terkaya Indonesia menguasai 49,3 \% kekayaan nasional. Berdasarkan laporan dari BPS pada Maret tahun 2016 Indeks Gini Ratio Indonesia berada di angka 0,397. Artinya tingkat ketimpangan sangat tinggi. Bahkan data Bank di Indonesia didominasi oleh pemilik rekening di atas Rp 2 Miliar. Meskipun hampir $98 \%$ jumlah rekening di bank dimiliki oleh nasabah dengan jumlah tabungan di bawah Rp 100 juta (BPS: 2007). Maka ini bisa memicu munculnya akar radikalisme dan fundamentaslime ekonomi.

Tugas pemerintah adalah membuat kebijakan yang bisa mengurangi ketimpangan ekonomi yang melahirkan jurang pemisah antara yang kaya dan miskin. Keempat hal di atas musti dilakukan agar gerakan terorisme ini semkain mengecil, dengan demikian mengelola negara yang bebas teroris bisa terwujud dengan baik. Bahkan kalau bisa ketimpangan ekonomi ini bisa dihilangkan. Sudah terlalu banyak korban jiwa karena gerakan terorisme yang sangat keji ini, dan kita tidak menginginkan korban jatuh lagi. Termasuk korban aksi teror koruptor sebagai kejahatan kemanusiaan.

\section{KESIMPULAN}

Mencegah dan meminimalisir korupsi adalah tugas bersama. Hanya saja negara harus hadir lebih tegas agar korupsi bisa dicegah dan jangan menimbulkan dampak yang lebih besar. Tetapi sebelum sampai kesana, korupsi juga merupakan teror dalam bentuk wujud yang lain. Perlu kebijakan negara denga tegas agar korupsi bisa berkurang sehingga kemiskinan sebagai dampak korupsi bisa teratasi dengan baik.

Kemiskinan sebagai pemicu terorisme bisa saja ditasi jika korupsi bisa dikurangi. Dalam hal inilah negara perlu punya konsep, desain, metode dalam pemberantasan korupsi sehingga dampak korupsi dan dampak kemiskinan dalam wujud munculnya benih radikalisme dan terorisme bisa makin berkurang.

Kolaborasi antara masyarakat sipil (civil society), aparat penegak hukum, swasta, dan pemerintah sangat ampuh untuk memperkecil ruang bagi pelaku teror. Kemudian pengentasan kemiskinan berbasis pemberdayaan pada masyarakat merupakan langkah yang sangat ampuh agar gerakan radikalisme tidak tumbuh 
dalam ruang publik kita. Pemberantasan korupsi bisa jadi jalan utama menuju kesejahteraan masyarakat karena dalam masyarakat sejahtera benih radikalisme akan semakin mengecil.

\section{DAFTAR PUSTAKA}

Abuza, Zachary, "Political Islam and Violence in Indonesia", Lynne Rienner Publishers 2007

Giraldo \& Trinkunas, Terorisme financing, Stanford University Press, Bersteker \& Eckert, eds, 2008

Huntington P, Samuel, Political Order in Changing Societies, mendefinisikan korupsi sebagai behavior of public officials with deviates from accepted norms in order to serve private ends, 2001.

Indonesia Dalam Angka, BPS, 2007

Sugiyono, Prof, Metode Penelitian Kuantitatif dan R\&D, Alfabeta, Bandung, 2010

Muhammad Azhar (Et.al), Pendidikan Antikorupsi, (Yogyakarta: LP3 UMY, Partnership, Koalisis Antarumat Beragama untuk Antikorupsi, 2003

Rajagukguk, Jonson, Teror Makassar Vs Teror Koruptor, Harian WASPADA, April, 2021.

Singarimbun dan Effendi. 1995. Metode Penelitian Survey.Jakarta: PT. Pustaka LP $_{3}$ ES. Sugiyono. 2002. Statistik untuk Penelitian Bandung: Alfabeta. 